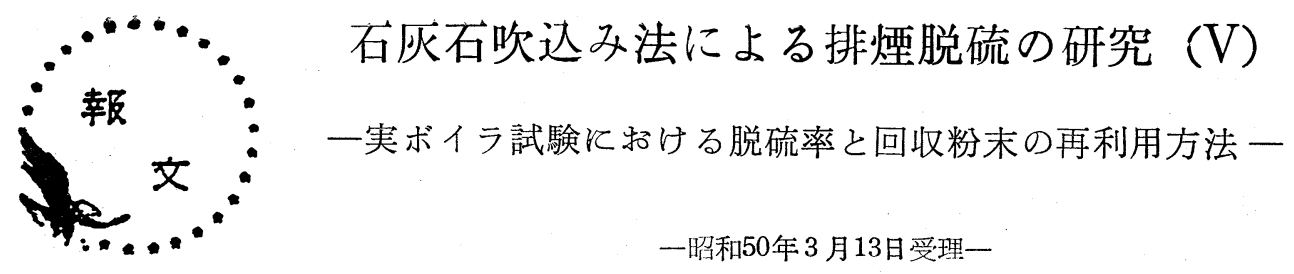

福 沢年

浅川仲平

\section{1. まえがき}

石灰吹込み法による排煙脱硫の研究の一環として, 発電用ボイラーの適用方法とボイラ内で進行する石灰 石の熱分解反応拉よび生石灰と $\mathrm{SO}_{2}$ との反応の平衡 論的考察を第 1 報に，石灰石吹込久法の脱硫率に扮よ ぼす諸反応条件の影響と脱硫率の推算方法を第 2 報 に, 脱硫反応速度に対する諸反応条件の考察を第 3 報 に, 生石灰粉末と $\mathrm{SO}_{2}$ との反応の物質移動論的考察 を第 4 報に報告した。

本報告では発電用ボイラに执いて行なった石灰石吹 込久試験で得られた脱硫率の考察, 石灰石吹込久法の ボイラーの適用上の問題叔よび集塵器に捕集される石 灰粉末の再使用方法などについて述べる。

実ボイラ試験は電力中央研究所排ガス対策研究委員 会 $\mathrm{SO}_{2}$ 専門部会が企画して, 中部電力名港火力発電 所 8 号ボイラ (55MW) と三重火力発電所 3 号ボイラ $(75 \mathrm{MW})$ 飞执いて，中部電力と電力中央研究所の共 同により，それぞれ40年10月特よび 42 年 7 月実施し，

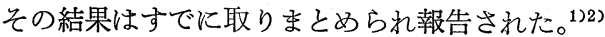

本報告では, 上記試験で得られた脱硫率と室内実験 で得られる脱硫率との間の関係について考察する。

\section{2. 実ボイラ試験の脱硫率}

\section{1 供試ボイラと試験方法}

石灰石吹込久試験を実施した 2 ボイラの主な仕様を つぎに示す。

（1）名港火力発電所 8 号ボイラ

発電機出力 $55 \mathrm{MW}$

蒸発量 $230 \mathrm{t} / \mathrm{h}$

燃焼方式 コーナ・ファイヤリング

微粉炭機 チーブミル $12 \mathrm{t} / \mathrm{h} \times 4$ 台

重油バーナ 圧力嘪霧式 3 段 $\times 4$ 隅

機械式集塵器 ブローダウン型パラクロン
(2) 三重火力発電所 3 号ボイラ 発電機出力 $75 \mathrm{MW}$

蒸発量 $260 \mathrm{t} / \mathrm{h}$

燃焼方式 コーナ・ファイヤリング

重油バーナ 圧力嘪霧式 4 段 $\times 4$ 隅

機械式集塵器 マルチサイクロン

電気式塵器 ウエスタン型乾式

いずれの試験においても，石灰石吹込み試験は既設 の微粉炭燃焼用設備をできる限り利用して行なった。

名港拈よび三重のボイラは重油と石炭を任意の割合 で燃焼可能な設備を有しているので，試験期間中のボ イラ運転は重油専焼で行ない, 石炭燃燒用設備の一部 を使用して石灰石粉末をボイラ内へ吹込んだ。すなわ

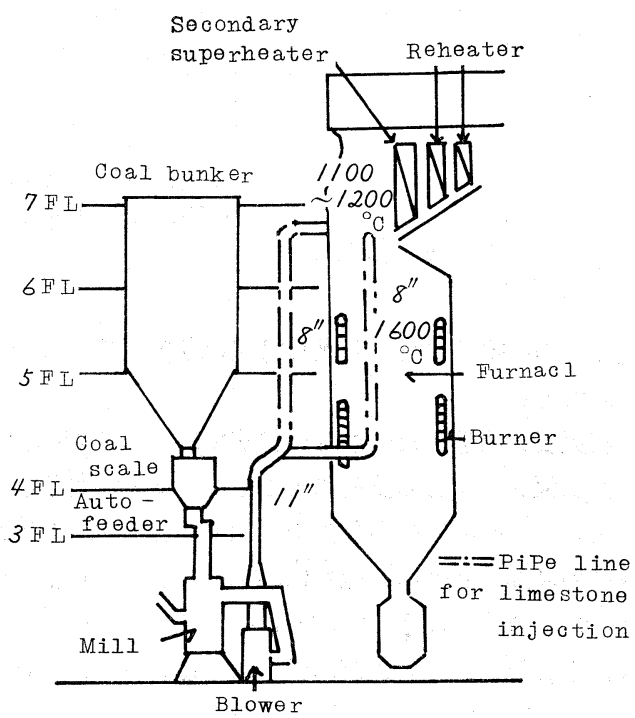

Fig. 1 Limetone injection system in the boiler at the Mie Power Station 
ら, 石灰石をバンカーに投入し, 石炭計量機, 微粉炭 機, 排炭機, 送炭管を通って石炭バーナ（名港火力発 電所）または火炉上段に新設した吹込み孔（三重火力 発電所) からボイラ内へ吹込んだ。(Fig. 2 参照)

名港火力発電所の試験では滋賀県醒ケ井座および京 都府質志産の石死石を微粉炭機で粉砕して吹込んだ が，三重火力発電所の試験では粉末状の石灰石, 消石 灰などを使用し，微粉炭機を素通りさせてボイラ内へ 吹込んだ。

\section{2 試験結果}

\subsection{1 名港火力石灰石吹込及試験の脱硫率}

名港火力発電所で行なった石灰石吹込及試験では, 既設の石炭バーナ最上段からボイラ火炉内の燃焼領域 (ガス温度 $1,600 \sim 1,700^{\circ} \mathrm{C}$ ) 几吹込んだ。ボイラから 煙突まで 2 つ煙道 (AとB) に分れているので, 両 煙道の $\mathrm{SO}_{2}$ 濃度測定值から求めた全試験の脱硫率を 石灰石吹込又量に対してプロットして Fig. 2 に示 す。A，B両ダクトで脱硫率が若干異なる理由は, 燃

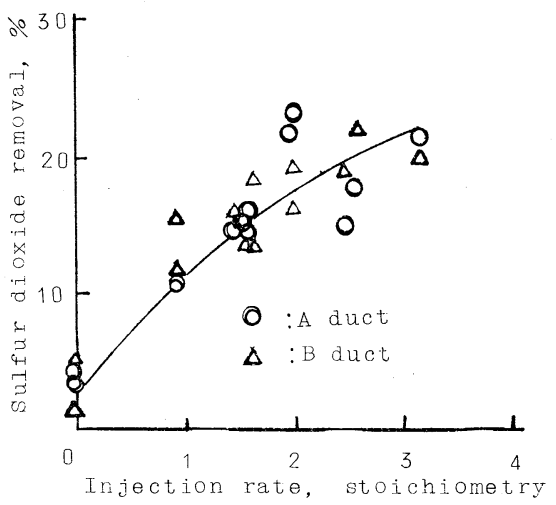

Fig. 2 Sulfur dioxide removal by limestone injected into the boiler at Meiko Power Station

焼ガス中へ吹込まれた石灰石粉末の分散が均一でない ためである。

石灰石を吹込まない場合の脱硫率はボイラ内に付着 した石灰ダストとの反応によるものであり，付着状況 によって 1〜5\% の範囲内で変動した。石灰石の吹込 又量の堌加とともに脱硫率は増加したが，その值は吹 込及量が $\mathrm{SO}_{2}$ に対して 1 当量秥よび 2.5 当量のと き，それぞれ12\%抽よ゙20\%に過ぎなかった。すなわ ら, 反応塔式 $\mathrm{SO}_{2}$ 除去実験装置の $1,100^{\circ} \mathrm{C}$ のガス中 一同一石灰石を吹込んで得られる脱硫率の $1 / 2$ 以下に 過ぎなかった。また，本試験では，鉄分が多い京都府
質志産石灰石 $\left(\mathrm{Fe}_{2} \mathrm{O}_{3} 0.93 \%\right)$ の使用，反応促進剂之 して黄土添加などの試験も行なったが，いずれも効果 は認められなかった。

以上のように，本試験の脱硫率が低かった理由は， 吹込まれた石灰石の熱分解によって生成した生石灰が 過度の高温下に曝されたために焼き締って比表面積が 小さくなり， $\mathrm{SO}_{2}$ との反応性が低下したためであると 考学られる。

\section{2 .2 三重火力石灰石吹込久試験の脱硫率}

名港火力発電所で行なった石灰石吹込み試験では高 温過ぎる燃焼ガス中へ吹込んだため，著しく低い脱硫 率が得られたに過ぎなかった。そこで, 三重火力発電 所で行なった石灰石吹込久試験では，最適温度域に石 灰石を吹込むことを目的として，ボイラ火炉上段に新 たに 5 力所の吹込み孔を設けた。(Fig. 3 参照)

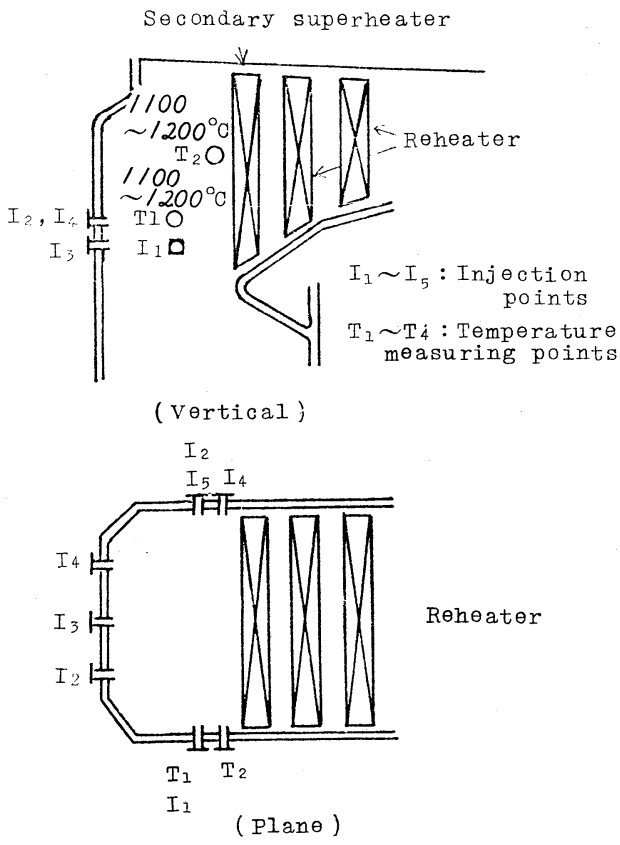

Fig. 3 Injection points and measuring points

本試験には，同一産地の石灰石を粉砕して得た粒径 の異なる 3 種類の石灰石粉末を用いた。また，消石灰 および集塵器に捕集された石灰粉末の水和物も試験に 供した。これらの化学組成を Table 1 に示す。さら に, 本試験では消石灰スラリーの吹込み試験も行なっ た。すなおち，ミキサーで濃度10\%の消石灰スラリー を作り，グラウトポンプで火炉上段まで圧送し，5ケ 所の吹込み孔（新設）からポイラ内へ噴霧して吹込ん 
Table 1 Chemical analyses data of the limestones, hydrated limes and hydrated sorbents recovered in precipitator

Sorbents

Chemical Compositione, \%

Limestone $(10 \mu)$

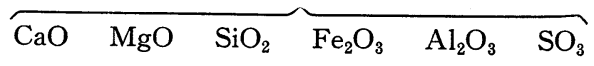

Weight
Loss
$\%$

43. 1

43.5

$55.1 \quad 0.60$

0.44

0.08

0.16

0.17

0.37

0.10

$54.4 \quad 1.27$

0.37

0.09

0.17

$-$

68.32 .82

2.64

0.13

0.39

0.45

$61.7 \quad 0.90$

1. 08

Hydrated Sorbent

だ。

本試験で得られた脱硫率を Fig. 4 に示す。石灰石 粉末を $\mathrm{SO}_{2}$ に対して 2 当量吹込んだ場合の脱硫率は
約 $40 \%$ が得られ，消石灰粉末を 2.6 当量吹込んだ場合 に最高の脱硫率約 $60 \%$ が得られた。

重油専焼時に測定した石灰石吹込み位置の燃焼ガス

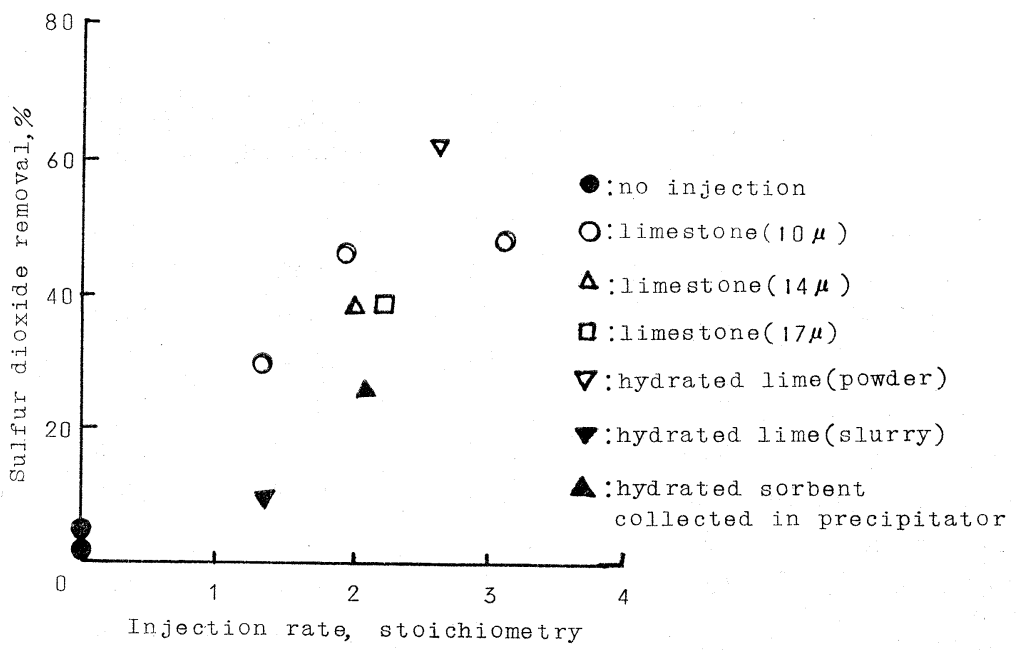

Fig. 4 Sulfur dioxide removal by limestone and hydrated lime injected into the boiler at Mie Power Station

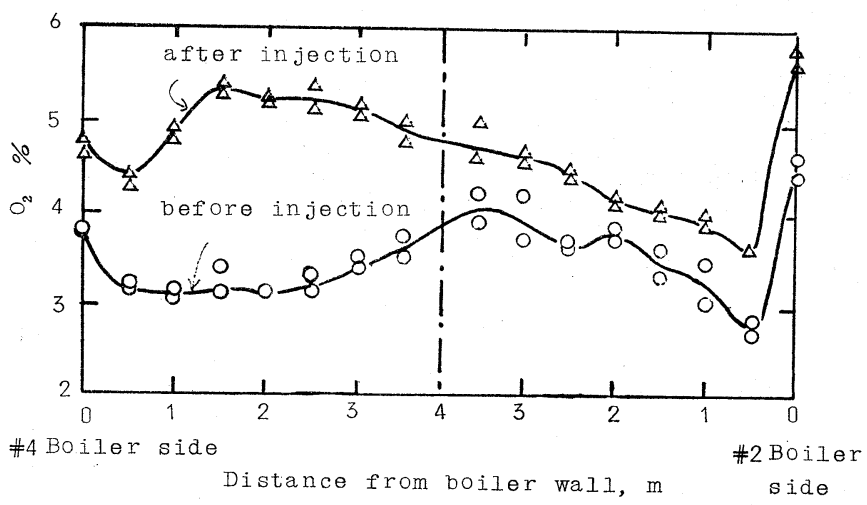

Fig. 5 Oxygene concentration distribution across the boiler in front of the secondary superheter before and after injection of limestone 
温度は $1,100 \sim 1,200^{\circ} \mathrm{C}$ の範囲内にあったので，石灰石 などの吸収剤粉末はいずれも適温域に吹込まれたと判 断される。

石灰石粉末はポイラ内へ空気とともに吹込んだの で，吹込反前後の燃焼ガス中の酸素濃度增加から石灰 石粉末の分布の均一性を推定することができる。石灰 石吹込又位置から約 $5 \mathrm{~m}$ 後流のボイラ断面 (2 次過熱 器前面）に打いて測定した酸素濃度分布を Fig. 5 に 示す。 同図からわかるよらに，4号缶側の方が 2 号 缶側よりも酸素濃度の增加が大きかった。したがっ て, 吹込委れた石灰石粉末は 4 号缶側の方へ多量に吹 込まれたと推定された。このことは, 2 次過熱器出口 (ガス温度約 $900^{\circ} \mathrm{C}$ ) 飞执いて, 4 号缶側の側壁から
奥行き $1.7 \mathrm{~m}$ のガス中の $\mathrm{SO}_{2}$ 濃度から求めた脱硫率 が平均脱硫率よりも1.5〜2.0倍高かったことによって 立証された。

\section{2 .3 脱硫率の考察}

燃焼ガス中の $\mathrm{SO}_{2}$ は，燃焼ガス中に吹込まれた石 灰石粉末とのガス中に拈ける反応およびボイラ内の高 温伝熱面上に付着した石灰粉末との反応の両者によっ て減少する。前者による脱硫率は石灰反応率と吹込み 量（当量）との積として求められ，後者による脱硫率 は全脱硫率と前者による脱硫率の差として求められ る。

三重火力発電所に拈ける試験で得られた脱硫率の内 訳を上記のように区分して Table 2 に示す。同表か

Table 2 Items of the sulfur dioxide removal

\begin{tabular}{|c|c|c|c|c|c|c|}
\hline $\begin{array}{l}\text { Run } \\
\text { No. }\end{array}$ & Absorbents & $\begin{array}{l}\text { (1) } \\
\text { Total } \mathrm{SO}_{2} \\
\text { removal, } \\
\%\end{array}$ & $\begin{array}{l}\text { 2) } \\
\text { Ratio of } \\
\text { reacted } \\
\text { lime, } \%\end{array}$ & $\begin{array}{l}\text { (3) } \\
\text { Amount of } \\
\text { injection, } \\
\text { stoichiomety }\end{array}$ & $\begin{array}{l}\text { (4) } \\
\mathrm{SO}_{2} \text { removal } \\
\text { in the gas, } \\
\%,(2) \times(3)\end{array}$ & $\begin{array}{l}\mathrm{SO}_{2} \text { removal } \\
\text { reacted with } \\
\text { deposit, } \% \\
\text { (1)-(4) }\end{array}$ \\
\hline 1 & Oil firing only & 1.4 & 0 & 0 & 0 & 1.4 \\
\hline 2 & Limestone $(10 \mu)$ & 46.2 & 15.34 & 1.93 & 29.6 & 16.6 \\
\hline 3 & Limestone $(10 \mu)$ & 29.9 & 16.75 & 1. 31 & 21.9 & 8.0 \\
\hline 4 & Limestone $(10 \mu)$ & 48.1 & 11.98 & 3.08 & 36.9 & 11.5 \\
\hline 5 & Limestone $(17 \mu)$ & 38.2 & 11. 20 & 2.17 & 24.3 & 13.9 \\
\hline 6 & Limestone $(14 \mu)$ & 38.2 & 10.56 & 1.98 & 20.9 & 17.3 \\
\hline 7 & Hydrated lime powder & 61.6 & 13.79 & 2.58 & 35.8 & 25.8 \\
\hline 9 & Hydrated sorbent & 25.4 & $19.50^{1)}$ & 2.05 & 12.1 & 10.1 \\
\hline 10 & Hydrated lime slurry & 9.1 & 4.3 & 1. 39 & 6.0 & 3.1 \\
\hline
\end{tabular}

1) The ratio of reacted lime of the hydrated sorbent before injection is $13.60 \%$

らわかるように，付着物との反応による脱硫率は全脱 硫率の30〜80\%を占め，粒径が小さくなるほど高くな る傾向があった。

付着物との反応による脱硫率は, Fig. 6 に示すよう に, 付着量の増加にともなら脱硫率の増加速度の大き いものほど高かった。一方, 付着量の増加は伝熱阻害 も增加させるのでボイラの蒸気温度が低下して安定な 運転が困難になる。したがって, 実用的な観点からは 付着物との反応による脱硫率が高くなるような石灰石 吹込み条件は望ましくない。

Table 2 に示した吸収剤粒径と石灰反応率との関係 は Fig. 7 のように示される。すなわら, 石灰反応率 が吸収剤粒径の $1 / 2$ 乗に反比例する関係にあり, 室内 実験で得られた粒径の $1 / 3$ 乗に反比例する関係と近似 している。

2.2.4 ボイラ内の反応温度域

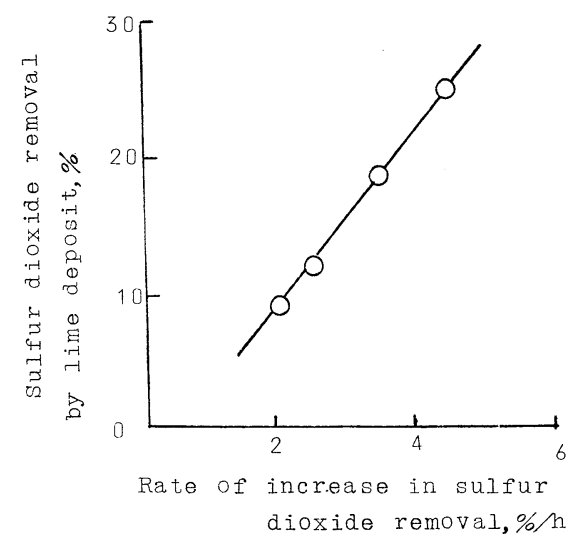

Fig. 6 Relation between sulfur dioxid removal by lime deposit and rate of increase in sulfur dioxide removal 


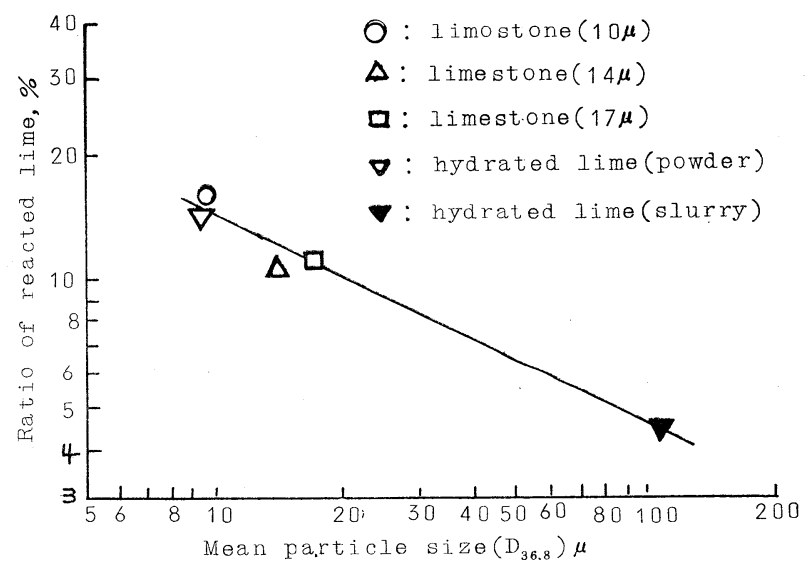

Fig. 7 Relation between ratio of reacted lime and particle size of sorbents

試験終了後ボイラ内に入って各所に付着した石灰ダ ストを採取し，それぞれに含まれる $\mathrm{CaSO}_{4}$ の割合の 分析值とダスト付着部のガス温度との関係を示すと Fig. 8 が得られる。同図はガス温度 $600^{\circ} \mathrm{C}$ 以下の伝 熱面上に付着した石灰ダスト中の $\mathrm{CaSO}_{4}$ の含有量が 一定であることから, $\mathrm{SO}_{2}$ と $\mathrm{CaO}$ との反応は $600^{\circ} \mathrm{C}$ 以下では著しく遅いと考光られる。一方 $900^{\circ} \mathrm{C}$ 以上の 温度域に付着した石灰ダストは $\mathrm{CaSO}_{4}$ の含有量が80

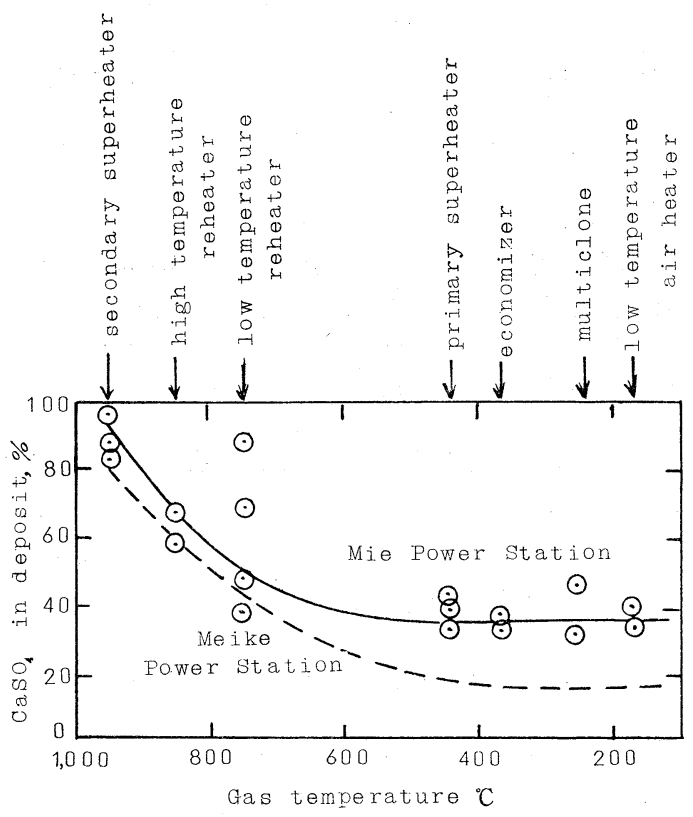

Fig. 8 Relation between calcium sulfate in deposits and gas temperature in the boiler
\%以上であったことから，反応時間が長ければ $\mathrm{CaO}$ 粒子の内部まで $\mathrm{SO}_{2}$ との反応が進行することがわか る。

\section{3. 実ボイラ試験と室内実験との脱硫率の相関}

\section{1 石灰反応率の比較}

第 2 報で述べた各種石灰石の石灰反応率と粒径との 関係のうちから, 通常の石灰石および奄美群島産石灰 石の 2 種を選び, これと名港火力発電所および三重火 力発電所に和ける実ボイラ試駼結果を合せて Fig. 9 と示す。

同図からかかるように，名港火力発電所拉よび三重 火力発電所に括ける試験で得られた石灰反応率はそれ ぞれ室内実験で得られた值の約60\%抽よび80\%であっ た。実ボイラ試験に和ける石灰反応率がこのように低 かった理由は, 三重火力発電所に和ける試験に款いて はボイラ内へ吹込んだ石灰石粉末のガス中に扔ける分 散の不均一によるものであり, 名港火力発電所に和け る試験に括ていは石灰石粉末を吹込んだ場所の燃焼ガ ス温度が高過ぎたためであると考兄られる。

\section{2 実ボイラ試験の脱硫率の推定}

ボイラ内一石灰石粉末を吹込んで得られる脱硫率 は, 同一産地の石灰石粉末を反応塔式 $\mathrm{SO}_{2}$ 除去実験 装置内一吹込んで得られる石灰反応率之両者の反応条 件から次式によって求められる。

$$
\begin{aligned}
& \eta_{p}=R_{p} \cdot S_{t}+\eta_{W} \\
& R_{p}=A \cdot B \cdot R_{t}\left(\frac{D_{t}}{D_{p}}\right)^{0.3}\left[\frac{\left(\mathrm{SO}_{2}\right)_{p}}{\left(\mathrm{SO}_{2}\right)_{t}}\right]^{0.4}
\end{aligned}
$$

$\eta_{p}:$ 実ボイラに和ける脱硫率 [一] $R_{p}:$ 実ボイラに怙ける石灰反応率 [一] 


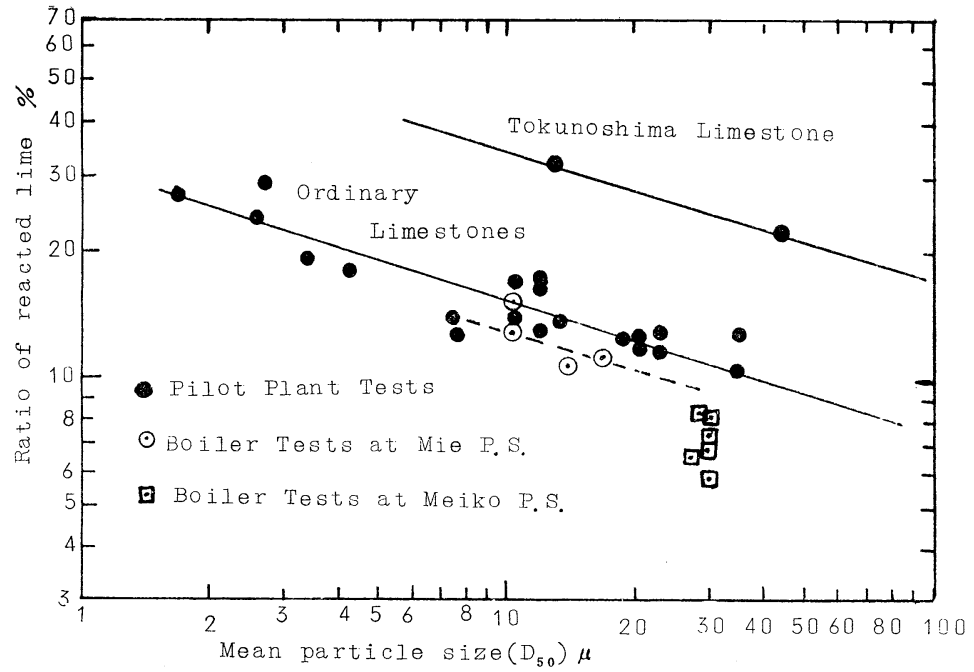

Fig. 9 Comparison of the reactivities of limestones injected into the boilers and the pilot plant

$S_{t}$ : 石灰石の吹込量のガス中の $\mathrm{SO}_{2}$ に対する 化学量論比 (当量比) [一]

$\eta_{W}$ : 壁面への吸収, 吸着による脱硫率 [一]

$R_{t}$ : 石灰石粉末を反応塔式 $\mathrm{SO}_{2}$ 除去実験装 置 の1,000 1, $200^{\circ} \mathrm{C}$ の゙ス中へ吹込んだ場合 の石灰反応率 [-]

$D_{p}$ : 実ボイラ内一吹込んだ石灰石粉末の粒径 $[\mu]$

$D_{t}$ ：反応塔式 $\mathrm{SO}_{2}$ 除去実験装置内一吹込んだ 石灰石粉末の粒径 $[\mu]$

$\left(\mathrm{SO}_{2}\right)_{p}$ : 実ボイラに特けるガス中の $\mathrm{SO}_{2}$ 濃度 $[\mathrm{pp}$ $\mathrm{m}]$

$\left(\mathrm{SO}_{2}\right)_{t}$ : 反応塔式 $\mathrm{SO}_{2}$ 除去実験装置に特けるガス 中の $\mathrm{SO}_{2}$ 濃度 $[\mathrm{ppm}]$

$A$ : 吹込み位置のガス温度による係数 [一]

ガス温度 $1,000 \sim 1,200^{\circ} \mathrm{C}$ のとき $A=1.0$ ガ ス温度 $1,500 \sim 1,700^{\circ} \mathrm{C}$ のとき $A=0.8$

$B$ : 吹込まれた石灰石粉末のガス中に和ける分 散の均一性を示す係数 [一]

分散が均一な場合 $B=1.0$

分散が良好な場合 $B=0.8$

分散が不均一な場合 $B=0 \cdot 6$

脱硫率が(1)式で表わされることは本報告の Table 2 に示したように明らかである。

実ボイラに活ける脱硫率が(2)式で表されることは， 第 2 報に示したように, 石灰反応率が粒径の約 $1 / 3$ 乗 に反比例, $\mathrm{SO}_{2}$ の約 0.4 乗に比例すること, 抢よび石
灰反応率が粒径分布の不均一あるいは吹込及位置のカ゚ ス温度の高過ぎにより低下することなどから理解する ことができる。

石炭專焼の $\mathrm{A}$ 火力発電所に执いて行なった石灰石吹 込々試験の石灰反応率と反応塔式 $\mathrm{SO}_{2}$ 除去実験装置 に同一石灰石粉末を吹込んだ場合の石灰反応率を比較 するとつぎのようであった。
反応条件

または結果

(1) 石灰石の種類

(2) 吹込及位置の ガス温度

(3) $\mathrm{SO}_{2}$ 濃度

(4) 石灰石粉末の 粒度

(5) 石灰反応率
$\mathrm{A}$ 火力発電所

徳之島石灰石

$1,200^{\circ} \mathrm{C}$

1,000ppm

200 メッシ通 過 $55 \sim 62 \%$

$7 \sim 13 \%$ (平均 $19 \%$ )
反応塔式 $\mathrm{SO}_{2}$ 除去実験装置 徳之島石灰石 $1,200^{\circ} \mathrm{C}$

1, 960ppm 左と同一粉末 を使用 $19 \%$
すなわら，ボイラ上段の仮設吹込み孔より石灰石を 吹込んだので $A=1.0, B=0.8$ とし， $R_{t}=19 \%$ ， $D_{t}=D_{p}, \quad\left(\mathrm{SO}_{2}\right)_{p}=1,000 \mathrm{ppm}, \quad\left(\mathrm{SO}_{2}\right)_{t}=1,960 \mathrm{ppm}$ を(2)式代入して $R_{p}$ を求めると，

$$
R_{p}=0.8 \times 19 \times\left(\frac{1,000}{1,960}\right)^{0.4}=11.2(\%)
$$

により石灰反応率の推算值 $11.2 \%$ が得られる。この值 は実測值 7 13\%（平均 10\%）とほぼ一致した。

(2) 式から石灰石吹达み法による実ボイラに括ける 石灰反応率をほぼ推定することができるので，脱硫率 は石灰石吹込久量と壁面への $\mathrm{SO}_{2}$ 吸収・吸着による 
脱硫率がわかれば(1)式によって求めることができる。

\section{4. 実ボイラへの適用上の問題}

石灰石吹込久法を実ボイラへ適用する際の問題点は つぎの諸点である。

(1) 脱硫率が低いこと

(2) ボイラ内へのダスト付着による運転上の障害

（3） 反応後の石灰粉末の利用法の開発

つぎに,これらの諸点について考察する。

\section{1 脱硫率}

石灰石吹込み法による脱硫率は，3章で述べたよう 飞，(1)，(2)式によって求められる。すなわち, 最高の 脱硫率を得るためには，反応性の最も大きい石灰石 (例兄ば徳之島産石灰石)を選び, 工業的に可能な限度 まで微粉碎し，ボイラの火炬上段からガス温度 1,100 $\sim 1,200^{\circ} \mathrm{C}$ の燃焼ガス中へできる限り多量に吹込むこ ガである。

しかしながら，ボイラの長期連続運転を可能とする ためには, ボイラの高温伝熱面 (2 次過熱器特よび再 熱器）上一の石灰ダストの付着をある限度内に抑える 必要があるが，次節で述べるようにダストの付着量は 石灰石の吹込及量の增加と微粉化とに比例して增加す るので，石灰石の吹込及量は重油消費量の $15 \%\left(\mathrm{SO}_{2}\right.$ $1,000 \mathrm{ppm}$ の場合は 3 当量に相当）が限度であり, 石 灰石粉末の粒度は平均粒径 $20 \mu$ 程度が工業的に利用可 能な粒径の限度と考えられる。

徳之島産の石灰石を平均粒径 $20 \mu$ 亿粉碎してボイラ の火炬上段からボイラ内の $1,100 \sim 1,200^{\circ} \mathrm{C}$ の温度域へ $\mathrm{SO}_{2}$ 飞対して 3 当量を吹込む場合の脱硫率を(1)，(2)式 から推算するとつぎのようになる。

すなわち， $A=1.0, B=0.8, R_{t}=25 \%$ (Fig. 9 よ り), $D_{t}=D_{p}=20 \mu, \quad\left(\mathrm{SO}_{2}\right)_{p}=1,000 \mathrm{ppm}, \quad\left(\mathrm{SO}_{2}\right)_{t}=$ $2,000 \mathrm{ppm}$ であるから，(2)式より

$$
R_{p}=0.8 \times 25 \times\left(\frac{1,000}{2,000}\right)^{0.4}=14.7(\%)
$$

ボイラーのダスト付着を少なくしてボイラの運転上 の問題を生じなくすると，壁面への付着ダストによる 脱硫率は $5 \%$ 限度となろう。したがって，脱硫率は (1)式よりつぎのように計算される。

$$
\eta_{p}=14.7 \times 3+5=49.2(\%)
$$

すなわち，石灰石吹込及法による脱硫率の限度は約 $50 \%$ と推定される。このように，脱硫率が低いことが 本方法の最大の欠点である。

\section{2 ボイラ内へのダスト付着}

重油専焼ボイラで石灰石吹込及試験を行なった場合 には，吹込み時間の経過とともに 2 次過熱器管および
再熱器管上へのダスト付着により管内蒸気温度が次第 に低下した。三重火力発電所で行なった試験に和ける 再熱器出口蒸気温度の降下速度は Fig. 10 扤よび Fig. 11 に示すように，

（1）石灰石の吹込み量の增加

(2) 石灰石の粒径の減少

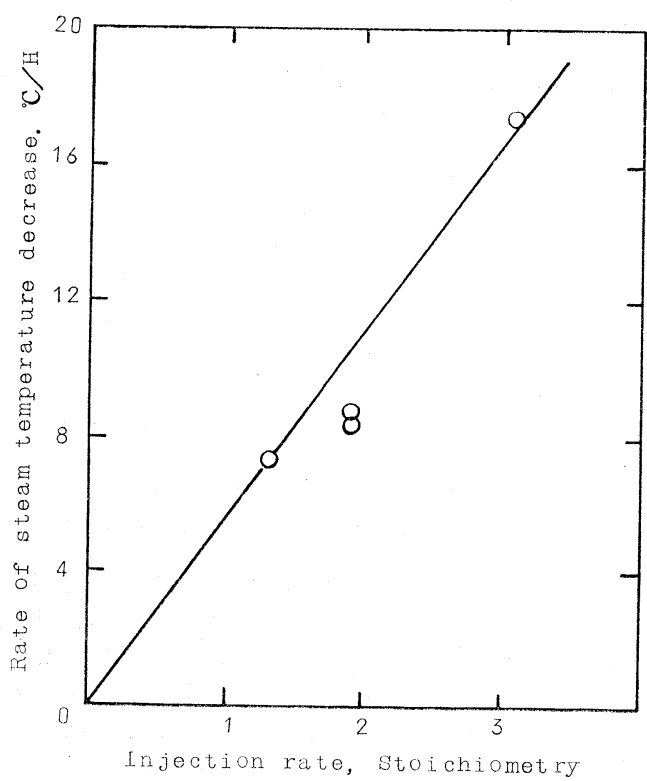

Fig. 10 Effect of the injection rate of limestones on the rate of steam temperature decrease in reheater

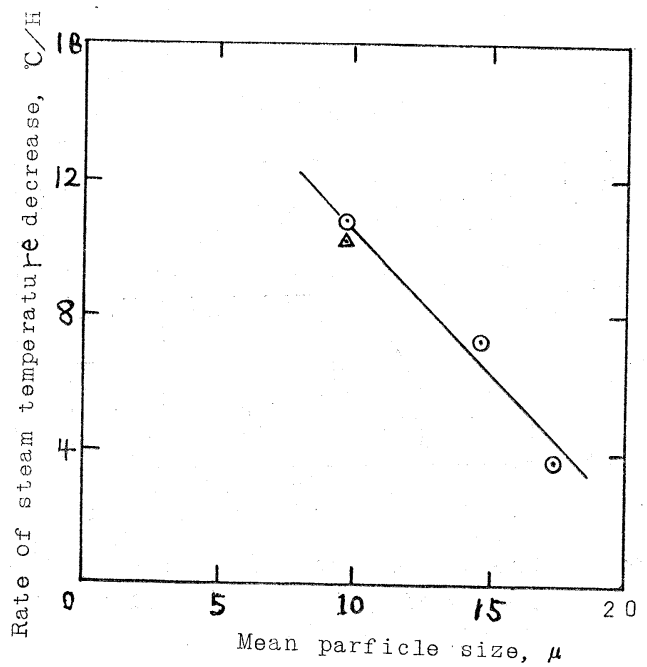

Fig. 11 Effect of the particle size of limestones on the rate of steam temperature decrease in reheater 
に比例して增加した。

この結果からわかるように，脱硫率を向上させるた め石灰石吹込久量を增加あるいは石灰石粉末を微粉化 するとダスト付着量が增加して過熱蒸気温度が降下す るので正常なボイラ運転が阻害される和それがある。 これを防止するためには，石灰石の吹込久量と微粉化 を制限する必要がある。すなわち，脱硫率に限界が生 ごる。

石炭専焼ボイラでは石灰石吹込みにより 2 次過熱器 や再熱器上へのダスト付着はほとんどないので長期間
石灰石吹込みを継続しても蒸気温度の降下はなく，正 常にボイラ運転を継続できることがA火力発電所にお ける1か月の連続試験によって認められた。

\section{3 反応後の石灰粉末の再利用}

名港火力発電所 8 号ボイラへの京都府質志産石灰石 の吹込み試験拈よび三重火力発電所 3 号ボイラーの茨 城県常磐産石灰石の吹込又試験でそれぞれ集塺器に捕 集された粉末を末処理のまま，あるいは水和した後に 反応塔式 $\mathrm{SO}_{2}$ 除去実験装置内一再び吹込んだ場合の 石灰反応率は, Table 3 飞示したように, 水和後再吹

Table 3 Reactivity of spent lime recovered in precipitators

Rate of reacted lime \%

Mining districts
of limestones

Shichishi Kyoto

Jyoban, Ibaragi

$\overbrace{\text { In boiler } \begin{array}{c}\text { Th pilot } \\ \text { furnace }\end{array}}^{\text {(Limest injection }}$

6. $1^{b)}$

11. $2^{C)}$
32.1

15. 1
The second injection (Recovered sorbents ${ }^{a)}$ )

Without With
treatment hydration

$5.0 \quad 29.3$

8. $3 \quad 16.7$

Note: ${ }^{a)}$ Both recovered sorbents, untreated and hydrated, were injected into the pilot furnace

b) Gas temperature at injection point was 1,400 $1,600^{\circ} \mathrm{C}$

c) Gas temperature at injection point was $1,100 \sim$ $1,200^{\circ} \mathrm{C}$

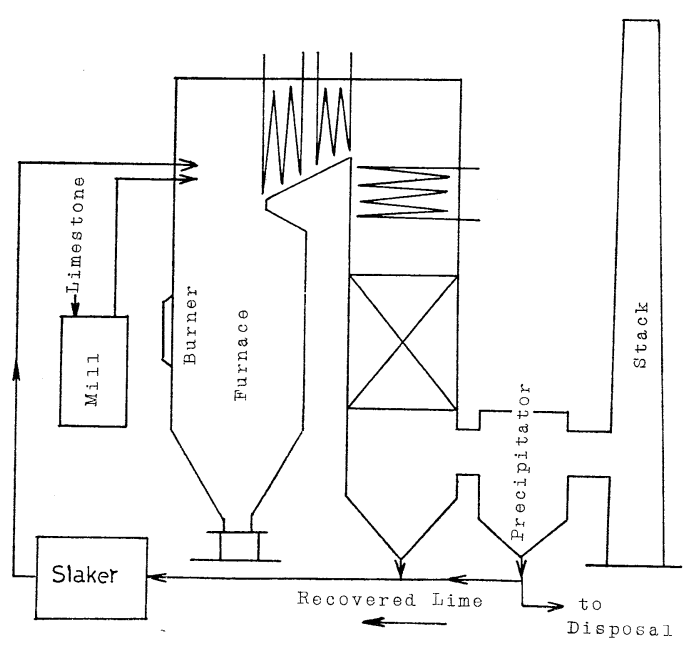

Fig. 12 Shematic diagram of recycle injection process of hydrated lime combined with limestone injection process

込みした方が著しく高い值が得られた。この值は新し い石灰石粉末を吹込んだ場合の石灰反応率にほぼ等し
かった。すなわち, 集塵器捕集粉末の水和再吹込み法 を Fig. 12 に示すように実ボイラへの石灰石吹込み 法へ応用すれば工業的に有利である。3)

三重火力発電所における試験においても上記の水和 再吹込み法の効果を確認するため，集塵器捕集粉末を 消石灰製造会社に送って水和してもらい，再びボイラ 内一吹込んだが, Table 2 に示したように, 水和再吹 込みによる石灰反応率の増加は $5.9 \%$ に過ぎなかっ た。このように水和再吹込みによる石灰反応率が低か った理由は水和が不完全であったことによると推定さ れたので，同じ粉末を完全水和後反応塔式 $\mathrm{SO}_{2}$ 除去 実験装置内一吹込んでその反応性を確めると, Table 3 に示したように，石灰反応率 $16.7 \%$ 年られ，同一 粒径の石灰石粉末を吹込んだ場合の石灰反応率とほぼ 等しかった。

水和により集塵器捕集粉末の反応性が向上する理由 はつぎのようであると考学られるすなわら，反応後 の石灰粉末は中心が未反応の生石灰，表層が反応生成 物である緻密な $\mathrm{CaSO}_{4}$ で覆われているが，水和する と中心部の $\mathrm{CaO}$ が $\mathrm{Ca}(\mathrm{OH})_{2}$ に変化する際の体積膨 
脹により, $\mathrm{CaSO}_{4}$ から成る外殼を破って $\mathrm{Ca}(\mathrm{OH})_{2}$ が 露出するようになる。そのため, $\mathrm{SO}_{2}$ との反応性が増 すと考光られ。

水和再吹込み法の利用によって石灰石の消費量を半 分程度まで少なくし得る見込みがあるが，いずれにし ても反応後の石灰粉末を系外一排出しなければならな い。この粉末を土木材料として利用する方法の研究 が当所に和いて行なわれ，すでに成果が得られてい る。 ${ }^{4)}$

$$
\text { 5. ま と }
$$

発電用ボイラで行なった 2 回の石灰石吹込み試験で 得られた脱硫率と実験装置で得られる脱硫率の考察か ら, 脱硫率の推算法, 集塵器捕集粉末の再使用方法に 関してつぎの成果を得た。

(1) 石灰石粉末をバーナ部からボイラ火炉内（ガス 温度 $1,600 \sim 1,700^{\circ} \mathrm{C}$ ) へ吹込んだ場合の石灰石 反応 率は火炉上段（ガス温度 $1,100 \sim 1,200^{\circ} \mathrm{C}$ ） 一吹込ん だ場合に比して著しく低い。

(2) 反応塔式 $\mathrm{SO}_{2}$ 除去実験装置への吹込み試験で 得られる石灰石粉末の石灰反応率から, 同じ産地の石 灰石粉末をボイラ内一吹込む場合の脱硫率の推算式を 導いた。

(3) 実ボイラに和ける石灰石吹込久法による脱硫率 は50\%程度が限度であると推定される。

(4) ボイラ内付着ダストによる脱硫率は付着量に比 例して増加するが，付着量の増加はボイラ運転上の障 害となる。

（5）集塵器捕集粉末の再使用方法として，これを水 和後再び吹込むことにより新しい石灰石粉末と同程度 の石灰反応率が得られることを見出した。
中部電力名港火力発電所および名港火力発電所で実 施した石灰石吹込久試験は, 電力中央研究所内に組織 された排ガス対策研究委員会 $\mathrm{SO}_{2}$ 専門部会で企画さ れ, 中部電力と電力中央研究所とが共同で実施したも のである。

本試験に御尽力戴いた中部電力の常務取 締役（当 時）河内武男氏, 常務取締役柴田二三男氏, 火力部長 (当時) 春口透氏, 加藤敬氏 (現在津支店長代理), 宮 島正郷氏 (現在火力室部長), 岸本昭氏 (現在知 多火 力発電所副調査役) 扣よび名港火力発電所, 三重火力 発電所の関係者の各位に感謝の意を表す。

電力中央研究所に护饬研究の遂行には, (元) 理 事関本賢一氏, (元) 理事平井弥之助氏, 通地信 義 氏 (現在相模工業大学教授), 研究顧問織田健一博士, 副 所長大塚唯男博士, 干葉徳男氏 (現在広島大学教授), 環境火気部次長星沢欣二氏の各位から御指導と御尽力 を戴いたこと, さらに当所の化学部と機械第一部の多 数の汃の協力を得たことについて感謝の意を表す。

\section{文献}

1) 電力中央研究所 排ガ ス対策研究委員会報告 No. 6 「石灰石吹込みによる $\mathrm{SO}_{2}$ 除去試験 報告」昭 和41年

2) 電力中央研究所 排ガ ス対策研究委員会報告 No. 8「三重火力発電所に拈ける亜硫酸ガ ス除去 試 験 報告書」昭和 42 年

3) 織田健一, 石原義巳; 日本特許 578, 118 (1970), アメリカ特許 $3,481,289$ (1969)

4) 関慎吾, 笠原清, 栗山武雄, 河角鄂; 電力中央研 究所技術第一研究所報告 68012 (1968)

\title{
Studies on Sulfur Oxides Removal from Flue Gas by Dry Limestone Injection Process (V)
}

\author{
- Sulfur Dioxide Removals at Full Scale Dry Limestone \\ Injection Tests and Reuse of Recoverd Lime-
}

by Yoshimi Ishihara, Hisasshi Hukuzawa and Chuhei Asakawa (Central Reserch Institute of Electric Power Industries)

SYNOPSIS :-Full scale dry limestone injetion tests were carried out in cooperation with Central Research Institute of Electric Power Inustries and Chubu 
Electric Power Company at the No. 8 boiler in Meiko Power Station and at the No. 3 boiler in Mie Pawer Station.

From those two field tests, the results are obtained as follows.

(1) From the ratio of reacted lime $\left(R_{t}\right)$ in the pilot furnace tests, the ratio in boiler $\left(R_{p}\right)$ will be given in next.

$$
R_{p}=A \cdot B \cdot R_{t}\left(\frac{D_{t}}{D_{p}}\right)^{0.3}\left(\frac{\left(\mathrm{SO}_{2}\right)_{p}}{\left(\mathrm{SO}_{2}\right)_{t}}\right)^{0.4}
$$

(2) Sulfur dioxide removal in boilers will be given as the sum of sulfur dioxiide removal by deposited lime and the products of the ratio of reacted lime and the amount of injected limestone.

(3) Sulfur dioxide removal by deposited lime increased with the increase in deposition. But it will cause troubles in boiler operation.

(4) We found that the hydrated sorbents recovered in precipitator will give the same sulfur dioxide removal as the new limestone when the hydrated sorbents are reinjected in to boilers. 